\title{
Pengendalian Kualitas Kantong Semen di PT. Industri Kemasan Semen Gresik Menggunakan Peta Kendali Demerit dan Fuzzy Demerit
}

\author{
Nanda Eka Putri R dan Diaz Fitra Aksioma \\ Departemen Statistika, Fakultas Matematika, Komputasi, dan Sains Data, \\ Institut Teknologi Sepuluh Nopember (ITS) \\ e-mail:diaz_fa@statistika.its.ac.id
}

\begin{abstract}
Abstrak-PT. Industri Kemasan Semen Gresik (PT. IKSG) merupakan salah satu anak perusahaan dari PT. Semen Gresik Tbk. (persero) yang bergerak dalam bidang pembuatan kantong semen. Seiring perkembangannya, PT. IKSG selalu berupaya meningkatkan mutu layanan dan kualitas produknya. Dalam menentukan kualitas produk, perusahaan melakukan pengendalian berupa menghitung proporsi cacat setiap line yang dibandingkan dengan batas toleransi kebijakan perusahaan. Pengendalian kualitas yang telah dilakukan tersebut memiliki kesamaran dalam memutuskan apakah proses pembuatan kantong semen telah terkendali sehingga perlu dilakukan pengendalian kualitas secara statistika. Pengendalian kualitas yang dilakukan menggunakan peta kendali demerit dan fuzzy demerit. Hasil peta kendali demerit dan fuzzy demerit menunjukkan proses produksi kantong semen jenis pasted di semua line selama periode Januari - Desember 2017 belum terkendali secara statistik. Peta kendali fuzzy demerit lebih sensitif dibandingkan dengan peta kendali demerit, dimana hal ini ditunjukkan oleh lebih banyaknya titik pengamatan out of control yang dapat ditangkap oleh peta kendali fuzzy demerit daripada peta kendali demerit. Adanya pengamatan out of control dominan disebabkan oleh faktor manusia dalam proses pembuatan adonan lem, penyetelan mesin dan bahan baku di awal produksi, kebersihan mesin, dan pemakaian mesin saat dilakukan perbaikan.
\end{abstract}

Kata Kunci-Kantong Semen, Pengendalian Kualitas, Peta Kendali Demerit, Peta Kendali Fuzzy Demerit.

\section{PENDAHULUAN}

$\mathrm{P}$ T. Industri Kemasan Semen Gresik (PT. IKSG) merupakan salah satu anak perusahaan dari PT. Semen Gresik Tbk. (persero) yang bergerak dalam bidang pembuatan kemasan atau kantong semen. Seiring perkembangannya, PT. IKSG selalu berupaya untuk meningkatkan mutu layanan dan kualitas produknya. Dalam menentukan kualitas produk, perusahaan melakukan pengendalian kualitas pada dua bagian yaitu pada kualitas bahan baku kertas kraft dan kualitas produk jadi kantong semen. Pengendalian kualitas produk jadi berupa kantong semen selama ini hanya dilakukan dengan menghitung proporsi cacat setiap line yang dibandingkan dengan batas toleransi persentase kebijakan perusahaan yang kemudian dilakukan pembuatan grafik garis untuk melihat apakah terdapat peningkatan proporsi cacat selama satu tahun. Oleh karena itu, terdapat kesamaran dalam memutuskan apakah proses pembuatan kantong semen di PT. IKSG telah layak atau tidak, sehingga perlu dilakukan pengendalian kualitas secara statistika.

Metode statistika memiliki banyak cara yang diterapkan dalam pengendalian kualitas. Salah satu metode statistika yang sering digunakan adalah peta kendali variabel dan atribut. Penelitian yang dilakukan dikhususkan pada produksi kantong semen dengan jenis pasted pada tahapan inspeksi. Cacat yang terjadi dapat lebih dari satu cacat dan antarjenis cacat dapat dikategorikan menjadi kelas cacat yang berbeda menurut tingkat keparahan cacat yang ditimbulkan.

Pengendalian kualitas yang sesuai dilakukan dengan kejadian cacat yang terjadi pada kantong semen di PT. IKSG adalah peta kendali atribut. Oleh karena jenis cacat yang terjadi dapat lebih dari satu cacat dan antarjenis cacat memiliki pembobot tertentu berdasarkan tingkat keparahannya, maka analisis pengendalian kualitas yang dapat digunakan adalah peta kendali demerit. Peta kendali demerit biasa atau classical demerit control chart (CDCC) mengasumsikan bahwa beberapa cacat pada satu kategori diperlakukan sama dan pembobot yang digunakan adalah pembobot crisp yang dipilih secara subjektif. Bagaimanapun, pembobot jenis cacat yang dikategorikan pada satu kelas cacat mungkin tidak setara. Apabila besar pembobot yang digunakan bernilai relatif atau tidak mutlak, maka pembobot tersebut dapat menyebabkan pengaruh yang signifikan pada performasi peta kendali demerit biasa. Untuk memperbaiki permasalahan ini, pembobot linguistik dapat digunakan dalam mengatasi pembobot di setiap kategori cacat melalui fuzzy set theory (FST) [1].

Tahapan inspeksi yang dilakukan oleh PT. IKSG mengamati empat jenis cacat pada kantong semen pasted kraft, yaitu cacat rusak, lengket valve, lengket bottom atas, dan lengket bottom bawah. Terdapat beberapa jenis cacat yang digolongkan pada cacat rusak, seperti cacat pada warna dan posisi logo perusahaan, serta kurang tepatnya bentuk kantong semen. Adanya beberapa jenis cacat pada satu kategori yang sama tersebut, apabila pembobot yang digunakan adalah pembobot crisp, maka dapat menyebabkan pengaruh yang signifikan pada performasi peta kendali demerit biasa. Selain itu, posisi cacat lengket valve dan lengket bottom atas yang saling berhimpit, dapat mengakibatkan proses pengeleman tercampur sehingga inspeksi yang dilakukan oleh operator menjadi kurang teliti. Oleh karena permasalahan tersebut, peta kendali fuzzy demerit atau fuzzy demerit control chart (FDCC) untuk pembobot akan lebih tepat digunakan pada penelitian ini untuk mendapatkan keputusan yang lebih akurat [2]. Peta kendali fuzzy sangat sesuai digunakan untuk pengamatan yang menghasilkan informasi yang tidak pasti, kurang jelas, dan berdasarkan subjektivitas atau persepsi seseorang.

Pengendalian kualitas pada kantong semen sebelumnya pernah dilakukan menggunakan peta kendali $p$ multivariat [3] dan peta kendali $p$ [4]. Kedua penelitian tersebut 
menghasilkan kesimpulan bahwa proses masih belum terkendali secara statistik. Penggunaan peta kendali demerit dan fuzzy demerit pernah dilakukan pada penelitian sebelumnya. Dengan menempatkan pembobot yang bervariasi pada kelas-kelas keparahan cacat yang berbeda, peta kendali demerit dalam beberapa hal memang efisien dalam mengungkap variasi abnormal dalam proses manufaktur, namun hal tersebut tidak berlaku ketika tingkat pembobotan dievalusi sebagai bilangan fuzzy karena pengelompokan cacat linguistik [5]. Penelitian tersebut mengusulkan monitoring proses dengan peta kendali fuzzy demerit. Dengan peta kendali fuzzy demerit, dapat dikatakan pengambian kesimpulan akan lebih sensitif jika dibandingkan dengan peta kendali demerit.

Berdasarkan latar belakang yang telah dijelaskan, pengendalian kualitas kantong semen di PT. IKSG pada penelitian ini menggunaka peta kendali demerit dan fuzzy demerit. Penelitian ini bertujuan untuk menentukan stabilitas proses produksi kantong semen di PT. IKSG dan untuk membandingkan hasil keputusan peta kendali demerit dan fuzzy demerit. Produk yang dilakukan analisis adalah jenis kantong pasted dan fungsi keanggotaan fuzzy yang digunakan adalah triangular.

\section{TINJAUAN PUSTAKA}

\section{A. Peta Kendali Demerit}

Peta kendali demerit merupakan peta kendali dimana jenis cacat dikategorikan menjadi beberapa kelas menurut tingkat kepentingan cacatnya [6]. Pola cacat produk secara umum berdasarkan bobot cacatnya dapat diberikan sebagai berikut.

1. Cacat kelas 1 (Very Serious), yaitu unit secara keseluruhan memiliki kecacatan yang tidak akan mudah diperbaiki, selain itu cacat pada unit dapat menyebabkan luka perseorangan atau kerusakan properti.

2. Cacat kelas 2 (Serious), yaitu unit akan meningkatkan biaya perawatan dan bisa mengalami cacat operasional kelas A sehingga mengurangi daya hidup produk.

3. Cacat kelas 3 (Moderately Serious), yaitu unit kemungkinan akan menyebabkan kegagalan dalam pelayanan, atau menimbulkan masalah yang tidak terlalu serius dibanding kegagalan operasional.

4. Cacat kelas 4 (Minor), yaitu unit memiliki ketidaksempurnaan dalam bentuk akhir, penampilan atau kualitas pekerjaan sehingga tidak akan menyebabkan kegagalan dalam pelayanan.

Langkah pertama dalam pembuatan peta kendali demerit adalah menghitung jumlah cacat terboboti untuk masing-masing subgrup pengamatan menggunakan persamaan berikut [7].

$$
D_{j}=w_{1} c_{j 1}+w_{2} c_{j 2}+w_{3} c_{j 3}+w_{4} c_{j 4}
$$

Nilai rata-rata cacat per unit pemeriksaan $\left(u_{j}\right)$ untuk masing-masing subgrup pengamatan yang berjumlah $m$ subgrup diperoleh dengan cara membagi jumlah cacat terboboti untuk masing-masing subgrup $\left(D_{j}\right)$ dengan banyaknya sampel pada subgrup pengamatan $\left(n_{j}\right)$ tersebut, dimana rumus yang digunakan adalah sebagai berikut.

$$
u_{j}=\frac{D_{j}}{n_{j}} ; j=1,2, \ldots, m
$$

Sedangkan jumlah rata-rata cacat per unit untuk jenis cacat terboboti secara keseluruhan $(\bar{u})$, diperoleh menggunakan persamaan:

$$
\bar{u}=w_{1} \bar{u}_{1}+w_{2} \bar{u}_{2}+w_{3} \bar{u}_{3}+w_{4} \bar{u}_{4}
$$

dimana nilai $(\bar{u})$ selanjutnya digambarkan sebagai center line (CL) pada peta kendali demerit. Sementara itu, nilai dari batas kontrol dapat digambarkan sebagai UCL (Upper Control Limit) dan LCL (Lower Control Limit) sebagai:

$$
\begin{aligned}
U C L & =\bar{u}+3 \hat{\sigma}_{u} \\
C L & =\bar{u} \\
L C L & =\bar{u}-3 \hat{\sigma}_{u}
\end{aligned}
$$

dengan nilai $\hat{\sigma}_{u}$ adalah:

$$
\hat{\sigma}_{u}=\sqrt{\frac{w_{1}^{2} \bar{u}_{1}+w_{2}^{2} \bar{u}_{2}+w_{3}^{2} \bar{u}_{3}+w_{4}^{2} \bar{u}_{4}}{n}}
$$

dimana $\bar{u}_{1}, \bar{u}_{2}, \bar{u}_{3}$, dan $\bar{u}_{4}$ menunjukkan rata-rata cacat per unit untuk kategori A, B, C, dan D yang diperoleh dengan rumus:

$$
\begin{aligned}
& \bar{u}_{1}=\frac{\sum_{j=1}^{m} c_{j 1}}{\sum_{j=1}^{m} n_{j}} \\
& \bar{u}_{2}=\frac{\sum_{j=1}^{m} c_{j 2}}{\sum_{j=1}^{m} n_{j}} \\
& \bar{u}_{3}=\frac{\sum_{j=1}^{m} c_{j 3}}{\sum_{j=1}^{m} n_{j}} \\
& \bar{u}_{4}=\frac{\sum_{j=1}^{m} c_{j 4}}{\sum_{j=1}^{m} n_{j}}
\end{aligned}
$$

dengan $j=1,2, \ldots, m$.

\section{B. Peta Kendali Fuzzy Demerit}

Peta kendali fuzzy berperan dalam pengendalian kualitas yang mengandung kesamaran (vagueness) seperti pada kecacatan produk. Penggunaan pembobot fuzzy dapat lebih menggambarkan klasifikasi kecacatan suatu produk. Salah satu peta kendali yang mengggunakan konsep fuzzy adalah fuzzy demerit. Setiap bobot linguistik dapat digambarkan sebagai bilangan fuzzy atau fuzzy number (FN), dengan demikian peta kendali fuzzy demerit dapat dibangun dari fuzzy set theory (FST) [2]. Langkah-langkah yang harus dilakukan dalam pembuatan peta kendali fuzzy demerit adalah sebagai berikut.

1. Pemilihan bobot linguistik cacat. Cacat yang terjadi pada inspeksi akan diklasifikasikan ke dalam $k$ kategori cacat yang berbeda berdasarkan bagaimana tingkat kecacatan produk. Setiap bobot linguistik digambarkan dengan triangular fuzzy number (TFN) positif, dimana fungsi keanggotaan pembobot linguistik ke- $i \quad \tilde{w}_{i}$ yang dinotasikan koordinat vektor $\left(\mathrm{w}_{\mathrm{i}, 1} / \mathrm{w}_{\mathrm{i}, 2} / \mathrm{w}_{\mathrm{i}, 3}\right)$ dapat didefinisikan sebagai berikut berdasarkan Gambar 1 .

$$
\mu_{\tilde{w}_{i}}(x)\left\{\begin{array}{cl}
\frac{x-\tilde{w}_{i, 1}}{\tilde{w}_{i, 2}-\tilde{w}_{i, 1}} & ; \tilde{w}_{i, 1} \leq x \leq \tilde{w}_{i, 2} \\
\frac{\tilde{w}_{i, 3}-x}{\tilde{w}_{i, 3}-\tilde{w}_{i, 2}} & ; \tilde{w}_{i, 2} \leq x \leq \tilde{w}_{i, 3} \\
0 & ; \text { lainnya }
\end{array}\right.
$$

2. Perhitungan ${ }^{\alpha_{c}} \tilde{D}_{j},{ }^{\alpha_{c}} U \tilde{C} L$, dan ${ }^{\alpha_{c}} L \tilde{C} L$. Jika pembobot linguistik ke- $i$ digambarkan dengan TFN positif $\tilde{w}_{i}$, 
maka ${ }^{\alpha_{c}} \tilde{w}_{j}$ dapat diperoleh dengan interval tertutup sebagai berikut.

$$
\alpha_{c} \tilde{w}_{i}=\left[w_{i, 1}+\alpha_{c}\left(w_{i, 2}-w_{i, 1}\right) ; w_{i, 3}-\alpha_{c}\left(w_{i, 3}-w_{i, 2}\right)\right]
$$

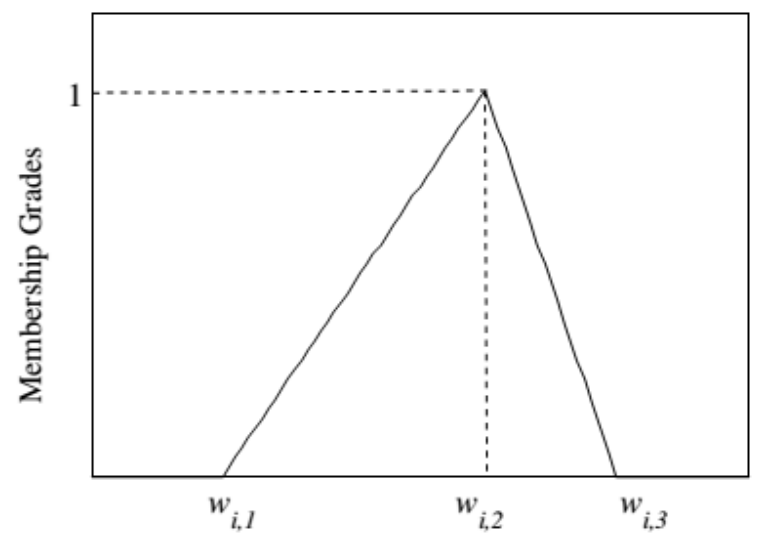

Gambar 1. Fungsi Keanggotaan TFN

Selanjutnya dengan menggunakan operasi aritmatika pada interval tertutup, ${ }^{\alpha} \tilde{D}_{j}$ dapat diperoleh berdasarkan perhitungan berikut.

$$
\begin{gathered}
{ }^{\alpha_{c}} \tilde{D}_{j}=\left[\sum_{i=1}^{k} c_{j i}\left(w_{i, 1}+\alpha_{c}\left(w_{i, 2}-w_{i, 1}\right)\right) ;\right. \\
\left.\sum_{i=1}^{k} c_{j i}\left(w_{i, 3}-\alpha_{c}\left(w_{i, 3}-w_{i, 2}\right)\right)\right]
\end{gathered}
$$

Selanjutnya untuk memperoleh ${ }^{\alpha_{c}} U \tilde{C} L$, dan ${ }^{\alpha_{c}} L \tilde{C} L, \alpha$-cuts dari $\tilde{C} L$, dan deviasi standar fuzzy $\sqrt{\sum_{i=1}^{k} \tilde{w}_{i}^{2} \bar{c}_{i}}$ perlu dihitung terlebih dahulu.

Oleh karena ${ }^{\alpha_{c}} C \tilde{L}={ }^{\alpha_{c}}\left(\frac{1}{m} \sum_{j=1}^{m} \tilde{D}_{j}\right)=\frac{1}{m} \sum_{j=1}^{m}{ }^{\alpha_{c}} \tilde{D}_{j}$, maka:

$$
\begin{aligned}
\alpha_{c} \tilde{C} L= & {\left[\frac{1}{m} \sum_{j=1}^{m} \sum_{i=1}^{k} c_{j i}\left(w_{i, 1}+\alpha_{c}\left(w_{i, 2}-w_{i, 1}\right)\right) ;\right.} \\
& \left.\frac{1}{m} \sum_{j=1}^{m} \sum_{i=1}^{k} c_{j i}\left(w_{i, 3}-\alpha_{c}\left(w_{i, 3}-w_{i, 2}\right)\right)\right] \\
= & {\left[\sum_{i=1}^{k} \bar{c}_{i}\left(w_{i, 1}+\alpha_{c}\left(w_{i, 2}-w_{i, 1}\right)\right) ;\right.} \\
& \left.\sum_{i=1}^{k} \bar{c}_{i}\left(w_{i, 3}-\alpha_{c}\left(w_{i, 3}-w_{i, 2}\right)\right)\right]
\end{aligned}
$$

Dengan cara yang sama, $\alpha$-cuts dari $\sqrt{\sum_{i=1}^{k} \tilde{w}_{i}^{2} \bar{c}_{i}}$ diturunkan pada Persamaan (11) jika $\bar{c}_{i}$ adalah bilangan ril lebih besar sama dengan 0 untuk semua $i$ adalah:

$$
\begin{aligned}
\left(\sqrt{\sum_{i=1}^{\alpha_{c}} \tilde{w}_{i}^{2} \bar{c}_{i}}\right) & =\sqrt{\sum_{i=1}^{k}\left(\alpha_{c} \tilde{w}_{i}\right)^{2} \bar{c}_{i}} \\
& =\left[\sqrt{\sum_{i=1}^{k} \bar{c}_{i}\left(w_{i, 1}+\alpha_{c}\left(w_{i, 2}-w_{i, 1}\right)\right)^{2}} ;\right. \\
& \left.\sqrt{\sum_{i=1}^{k} \bar{c}_{i}\left(w_{i, 3}-\alpha_{c}\left(w_{i, 3}-w_{i, 2}\right)\right)^{2}}\right]
\end{aligned}
$$

Maka nilai ${ }^{\alpha_{c}} U \tilde{C} L$ dan ${ }^{\alpha_{c}} L \tilde{C} L$ dapat dihitung dengan persamaan berikut.

$$
\begin{aligned}
{ }^{\alpha_{c}} \boldsymbol{U} \tilde{\boldsymbol{C}} \boldsymbol{L}= & {\left[\sum_{i=1}^{k} \bar{c}_{i}\left(w_{i, 1}+\alpha_{c}\left(w_{i, 2}-w_{i, 1}\right)\right)+\right.} \\
& L \sqrt{\sum_{i=1}^{k} \bar{c}_{i}\left(w_{i, 1}+\alpha_{c}\left(w_{i, 2}-w_{i, 1}\right)\right)^{2}} ; \\
& \sum_{i=1}^{k} \bar{c}_{i}\left(w_{i, 1}+\alpha_{c}\left(w_{i, 2}-w_{i, 1}\right)\right)+ \\
\alpha_{c} L \tilde{C} L= & {\left[\operatorname { m a x } \left(\sum_{i=1}^{k} \bar{c}_{i}\left(w_{i, 1}+\alpha_{c}\left(w_{i, 2}-w_{i, 1}\right)\right)-\right.\right.} \\
& \left.\sqrt{\sum_{i=1}^{k} \bar{c}_{i}\left(w_{i, 3}-\alpha_{c}\left(w_{i, 3}-\alpha_{c}\left(w_{i, 2}-w_{i, 1}\right)\right)^{2}\right.}, 0\right) ; \\
& \max \left(\sum_{i=1}^{k} \bar{c}_{i}\left(w_{i, 1}+\alpha_{c}\left(w_{i, 2}-w_{i, 1}\right)\right)-\right. \\
& \left.\left.\sqrt{\sum_{i=1}^{k} \bar{c}_{i}\left(w_{i, 3}-\alpha_{c}\left(w_{i, 3}-w_{i, 2}\right)\right)^{2}}, 0\right)\right]
\end{aligned}
$$

3. Kaidah keputusan setiap sampel inspeksi. Untuk sampel inspeksi ke-j yang dikumpulkan, $\tilde{D}_{j}$ dibandingkan dengan batas kendali fuzzy $U \tilde{C} L$ dan $L \tilde{C} L$. Perbandingan dapat dilakukan dengan membandingkan nilai-nilai right endpoint. Jika ${ }_{R}^{\alpha_{c}} \tilde{D}_{j}>{ }_{R}^{\alpha_{c}} U \tilde{C} L$ atau ${ }_{R}^{\alpha_{c}} \tilde{D}_{j}$ $<{ }_{R}^{\alpha_{c}} L \tilde{C} L$, maka peta kendali akan memberikan sinyal out of control.

\section{Proses Produksi Kantong Semen}

Proses produksi kantong semen di PT. IKSG jenis kantong pasted secara umum dapat dikategorikan menjadi dua tahapan utama yaitu pembuatan tube dan proses bottoming. Proses tubing atau sering disebut dengan pembuatan tube merupakan proses pembuatan kantong setengah jadi. Empat tahapan proses produksi pada pembuatan tube adalah pembuatan cap perusahaan, pembuatan lubang perforasi, pengeleman longitudinal, dan proses forming. Selanjutnya pada proses bottoming terdapat tahapan-tahapan yaitu pembuatan opening proses pengeleman dan forming, serta proses pressing. Apabila produk kantong semen telah jadi, maka dilakukan tahapan inspeksi, pengepakan, dan penyimpanan kantong.

\section{METODOLOGI PENELITIAN}

\section{Sumber Data}

Data yang digunakan dalam penelitian ini adalah data sekunder yang diperoleh dari bagian Jaminan Mutu di PT. IKSG pada tahapan inspeksi kantong semen yang dilakukan pada setiap shift I, II, dan III. Pengambilan sampel untuk pemeriksaan produk cacat dilakukan pada semua line yaitu line I hingga line VI. Data yang digunakan pada penelitian ini diambil pada bulan Januari - Desember 2017.

\section{E. Variabel Penelitian}

Penelitian ini menggunakan data pada proses produksi kantong semen pada tahapan inspeksi yang memiliki empat karakteristik jenis cacat. Keterangan keempat jenis cacat disajikan pada Tabel 1. 
Tabel 1.

Variabel Penelitian Proses Produksi Kantong Semen

\begin{tabular}{ll}
\hline \multicolumn{1}{c}{ Jenis Cacat } & \multicolumn{1}{c}{ Keterangan } \\
\hline Rusak & Warna print logo tidak sempurna, \\
& print logo melenceng, print logo \\
& hanya sebagian, bottom kantong \\
& semen tidak lurus atau menceng, \\
& kantong semen brodol \\
& Lengket pada bagian valve atau \\
Lengket Valve (LV) & corong tempat masuknya semen, \\
& dapat berupa lengket di tengah valve \\
& maupun di ujung valve \\
& Lengket pada bagian bottom atas \\
Lengket Bottom Atas & kantong \\
(LBA) & Lengket pada bagian bottom bawah \\
Lengket Bottom Bawah & kantong
\end{tabular}

Setiap jenis cacat pada Tabel 1 memiliki efek dan akibat yang berbeda-beda sesuai keparahan cacat yang ditimbulkan pada kantong semen. Oleh karena itu, perlu adanya pembobotan untuk masing-masing jenis cacat yang dapat merepresentasikan keparahan cacat yang diakibatkan. Pembobotan yang diberikan pada setiap jenis cacat sesuai dengan kebijakan perusahaan (based on expert) adalah sebagai berikut.

1. Cacat rusak sebesar $95 \%$.

2. Lengket valve sebesar $65 \%$.

3. Lengket bottom atas sebesar $25 \%$.

4. Lengket bottom bawah sebesar $15 \%$.

\section{Langkah Analisis}

Langkah analisis yang dilakukan berdasarkan tujuan penelitian adalah sebagai berikut.

1. Mengeksplorasi data kecacatan kantong semen.

2. Membuat peta kendali demerit.

3. Membuat peta kendali fuzzy demerit.

4. Membadingkan hasil keputusan peta kendali demerit dan fuzzy demerit.

5. Menarik kesimpulan dan saran.

\section{HASIL DAN PEMBAHASAN}

\section{A. Eksplorasi Karakteristik Jenis Cacat Kantong Semen}

Tabel 2.

Persentase Jumlah Cacat Berdasarkan Shift Setiap Line

\begin{tabular}{ccrrrrr}
\hline \hline \multirow{2}{*}{ Line } & \multirow{2}{*}{ Shift } & \multicolumn{5}{c}{ Jenis Cacat $(\%)$} \\
& LBA & LBB & LV & Rusak & Total \\
\hline \multirow{2}{*}{ I } & I & 0,71 & 1,47 & 1,39 & 0,85 & 4,42 \\
& II & 0,69 & 1,37 & 1,35 & 0,78 & 4,19 \\
& III & 0,68 & 1,36 & 1,37 & 0,77 & 4,19 \\
& I & 2,89 & 2,95 & 1,60 & 0,78 & 8,22 \\
II & II & 2,83 & 3,21 & 1,66 & 0,84 & 8,55 \\
& III & 3,94 & 3,95 & 1,82 & 0,87 & 10,59 \\
& I & 0,98 & 2,80 & 1,45 & 0,84 & 6,08 \\
III & II & 0,98 & 2,80 & 1,50 & 0,71 & 5,98 \\
& III & 0,95 & 2,74 & 1,53 & 0,83 & 6,04 \\
& I & 0,89 & 1,39 & 1,22 & 0,68 & 4,17 \\
IV & II & 0,95 & 1,35 & 1,26 & 0,70 & 4,26 \\
& III & 1,03 & 1,39 & 1,22 & 0,67 & 4,31 \\
& I & 1,17 & 1,52 & 1,11 & 0,66 & 4,47 \\
V & II & 1,23 & 1,65 & 1,17 & 0,66 & 4,72 \\
& III & 1,30 & 1,59 & 1,16 & 0,64 & 4,69 \\
& I & 0,30 & 0,55 & 0,58 & 0,42 & 1,86 \\
VI & II & 0,24 & 0,48 & 0,57 & 0,37 & 1,67 \\
& III & 0,23 & 0,46 & 0,55 & 0,39 & 1,63 \\
\hline \hline
\end{tabular}

Karakteristik masing-masing jenis cacat dapat dilakukan berdasarkan shift yang ditampilkan pada Tabel 2. Tabel 2 menunjukkan persentase jumlah kecacatan setiap shift dan line.

Total persentase jumlah cacat pada masing-masing line tidak selalu berada pada salah satu shift tertentu. Line I, III, dan VI memiliki total persentase jumlah cacat tertinggi pada shift $\mathrm{I}$, line $\mathrm{V}$ memiliki total persentase jumlah cacat tertinggi pada shift II, sedangkan line II dan IV memiliki total persentase jumlah cacat tertinggi pada shift III. Hal tersebut mengindikasikan bahwa shift tidak memengaruhi jumlah cacat yang terjadi karena baik shift I, II, maupun III sama-sama memiliki total persentase jumlah cacat tertinggi.

\section{B. Pengendalian Kualitas Kantong Semen dengan Peta} Kendali Demerit

Pada produksi kantong semen di PT. IKSG, cacat yang ditemukan pada produk kantong semen dapat diurutkan berdasarkan tingkat keparahan cacatnya. Dengan menggunakan pembobot yang sudah dijelaskan pada subbab III.B, maka dapat dilakukan perhitungan jumlah cacat terboboti untuk masing-masing sugrup sesuai. Perhitungan jumlah cacat terboboti berdasarkan Persamaan (1) pada line III dapat dilihat pada langkah berikut.

$$
\begin{gathered}
D_{1}=0,15(31)+0,25(8)+0,65(46)+0,95(21)=56,50 \\
\vdots \\
D_{508}=0,15(87)+0,25(19)+0,65(30)+0,95(30)=65,8
\end{gathered}
$$

Nilai $D_{j}$ tersebut kemudian digunakan untuk menghitung rata-rata cacat per unit pemeriksaan setiap subgrup menggunakan Persamaan (2), yaitu:

$$
\begin{gathered}
u_{1}=\frac{56,5}{2977}=0,01898 \\
\vdots \\
u_{508}=\frac{65,8}{3000}=0,02193
\end{gathered}
$$

Setelah dilakukan perhitungan jumlah cacat terboboti hingga rata-rata cacat per unit pada setiap subgrup, maka selanjutnya dapat dihitung nilai $\bar{u}$ pada setiap kelas dengan menggunakan Persamaan (6) sebagai berikut.

$$
\begin{aligned}
& \bar{u}_{1}=\frac{42297}{1519860}=0,0278 \\
& \bar{u}_{2}=\frac{14766}{1519860}=0,0097 \\
& \bar{u}_{3}=\frac{22597}{1519860}=0,0149 \\
& \bar{u}_{4}=\frac{12051}{1519860}=0,0079
\end{aligned}
$$

Kemudian nilai $\bar{u}$ pada setiap kelas tersebut digunakan untuk menghitung nilai $C L, U C L$, dan $L C L$ sesuai Persamaan (4) sehingga didapatkan:

$$
\begin{aligned}
U C L & =0,0238+3(0,0022)=0,0304 \\
C L & =0,0238 \\
L C L & =0,0238-3(0,0022)=0,0172
\end{aligned}
$$

yang selanjutnya nilai-nilai tersebut digunakan untuk membentuk peta kendali demerit line III seperti pada Gambar 2. Gambar 2 menunjukkan peta kendali demerit untuk monitoring proses produksi kantong semen di line III selama bulan Januari hingga Desember 2017. Terlihat pada Gambar 2 terdapat banyak titik pengamatan yang berada di luar batas kendali. Terdapat 276 titik pengamatan yang dinyatakan out of control dari total 508 pengamatan, 
sedangkan sebanyak 232 pengamatan berada di dalam batas kendali atau dengan kata lain dinyatakan in control.

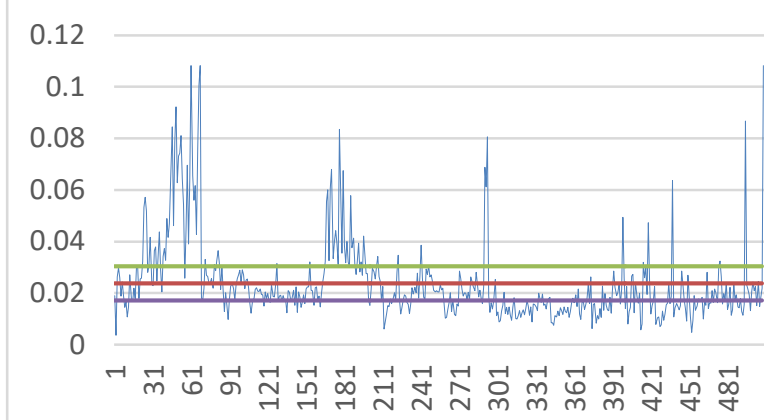

Gambar 2. Peta Kendali Demerit Produksi Kantong Semen Line III.

Adanya out of control mengindikasikan bahwa proses produksi pada 232 pengamatan tersebut tidak ditemukan adanya masalah, sedangkan 276 pengamatan lainnya yang dinyatakan out of control mengindikasikan adanya masalah pada proses produksi kantong semen di line III pada tahun 2017 yang menyebabkan keberlangsungan produksi masih belum terkendali secara statistik sehingga banyak ditemukan produk cacat yang tidak dapat ditoleransi berdasarkan tingkat keparahannya.

Kasus out of control yang terjadi di proses produksi kantong semen PT. IKSG secara umum disebabkan oleh faktor manusia atau operator di antaranya operator yang kurang tepat dalam melakukan setting awal mesin maupun bahan baku. Untuk jenis cacat lengket, terdapat empat penyebab utama yaitu viskositas lem tidak sesuai, kebersihan mesin tidak dijaga, setting awal ketebalan ruber set lem terlalu lebar, dan kesalahan setting awal ketebalan lem. Banyaknya kasus cacat yang outlier di beberapa subgrup disebabkan oleh adanya pemakaian mesin saat dilakukan perbaikan.

\section{Pengendalian Kualitas Kantong Semen dengan Peta Kendali Fuzzy Demerit}

Pembuatan peta kendali fuzzy demerit pada line III dapat dilakukan dengan tiga langkah berikut.

1. Pemilihan bobot linguistik cacat. Misalkan fungsi keanggotaan untuk pembobot linguistik setiap cacat didefinisikan sebagai bilangan fuzzy dalam koordinat vektor: "Rusak": $\quad \tilde{w}_{1}=(0 / 0,15 / 0,25)$, "LV": $\tilde{w}_{2}=(0,15 / 0,25 / 0,65)$, "LBA": $\tilde{w}_{3}=(0,25 / 0,65 / 0,95)$ dan "LBB": $\tilde{w}_{4}=(0,65 / 0,95 / 1)$.

2. Perhitungan $\alpha_{c} \tilde{D}_{j}, \quad \alpha_{c} U \tilde{C} L$, dan ${ }^{\alpha_{c}} L \tilde{C} L$. Sebelum melakukan perhitungan, perlu ditentukan terlebih dahulu $\alpha$-cuts yang akan digunakan, dimana nilai $\alpha$-cuts lebih dari 0,5 biasanya direkomendasikan. Pada penelitian ini nilai $\alpha$-cuts yang dipakai sebesar 0,8. Dengan Persamaan (8), maka ${ }^{\alpha_{c}} \tilde{w}_{j}$ dapat diperoleh sebagai interval tertutup sebagai berikut.

$$
\begin{aligned}
& { }^{\alpha_{c}} \tilde{w}_{1}=[0,12 ; 0,17] \\
& { }^{\alpha_{c}} \tilde{w}_{2}=[0,23 ; 0,33] \\
& { }^{\alpha_{c}} \tilde{w}_{3}=[0,57 ; 0,71] \\
& \alpha_{c} \tilde{w}_{4}=[0,89 ; 0,96]
\end{aligned}
$$

Selanjutnya dengan menggunakan operasi aritmatika pada interval tertutup, ${ }^{\alpha_{c}} \tilde{D}_{j}$ dapat diperoleh berdasarkan Persamaan (9) berikut.

$$
\begin{aligned}
D_{1}= & {[0,12(31)+0,23(8)+0,57(46)+0,89(21) ;} \\
& 0,17(31)+0,33(8)+0,71(46)+0,96(21)] \\
& =[50,47 ; 60,73] \\
& \vdots \\
D_{508}= & {[0,12(87)+0,23(19)+0,57(30)+0,89(30) ;} \\
& 0,17(87)+0,33(19)+0,71(30)+0,96(30)] \\
& =[58,61 ; 71,16]
\end{aligned}
$$

Dengan menggunakan $L=3$, maka nilai ${ }^{\alpha_{c}} U \tilde{C} L$ dan ${ }^{\alpha_{c}} L \tilde{C} L$ dengan persamaan (12) dan (13) dapat diperoleh :

$$
\begin{aligned}
\alpha_{c} U \tilde{C} L & =[63,145+3(5,998) ; 78,103+3(7,061)] \\
& =[81,140 ; 99,286] \\
\alpha_{c} L \tilde{C} L & =[\max (63,145-3(5,998), 0) ; \\
& \max (78,103-3(7,061), 0)] \\
& =[45,150 ; 56,20]
\end{aligned}
$$

3. Kaidah keputusan setiap sampel inspeksi. Setelah $\tilde{D}_{j}$ diperoleh berdasarkan perhitungan, selanjutnya $\tilde{D}_{j}$ dibandingkan dengan batas kendali fuzzy $U \tilde{C} L$ dan $L \tilde{C} L$. Perbandingan dapat dilakukan dengan membandingkan nilai-nilai right endpoint. Jika ${ }_{R}^{\alpha_{c}} \tilde{D}_{j}>$ ${ }_{R}^{\alpha_{c}} U \tilde{C} L$ atau ${ }_{R}^{\alpha_{c}} \tilde{D}_{j}<{ }_{R}^{\alpha_{c}} L \tilde{C} L$, maka peta kendali akan memberikan sinyal out of control. Pemilihan right endpoint yang digunakan pada pembuatan peta kendali fuzzy demerit dikarenakan oleh keputusan perusahaan dalam menggunakan pembobot yang cenderung tinggi untuk setiap jenis cacat. Selain itu, penggunaan right endpoint juga dapat mengantisipasi adanya kejadian jumlah cacat yang tinggi, sehingga dapat menimbulkan kerugian pada perusahaan. Apabila pembobot fuzzy yang digunakan berdasarkan left endpoint, maka peta kendali akan cenderung menghasilkan batas kendali yang lebih rendah sehingga tidak dapat mengantisipasi adanya kejadian jumlah cacat yang tinggi. Peta kendali fuzzy demerit dengan left endpoint juga tidak sensitif dalam mendeteksi kasus out of control pada pengamatan yang memiliki jumlah cacat terboboti kecil, sehingga jumlah kasus out of control yang diperoleh cenderung lebih sedikit daripada peta kendali demerit biasa. Nilai-nilai hasil perhitungan tersebut kemudian digunakan untuk membentuk peta kendali fuzzy demerit line III seperti pada Gambar 3.

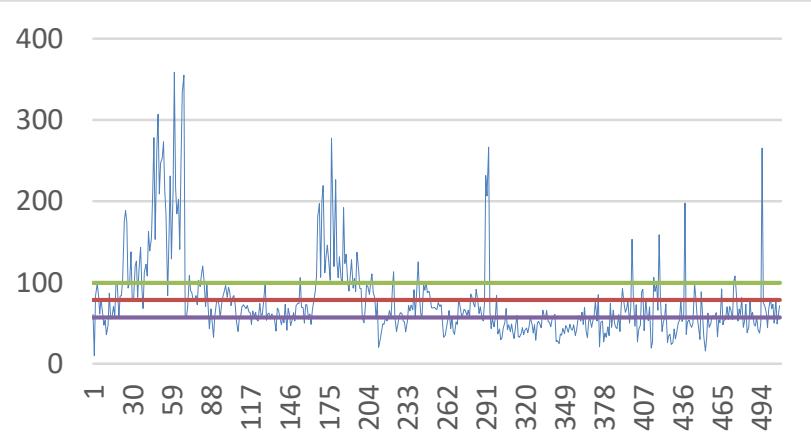

Gambar 3. Peta Kendali Fuzzy Demerit Produksi Kantong Semen Line III. 
Terdapat 287 titik pengamatan yang dinyatakan out of control dari total 508 pengamatan, sedangkan sebanyak 221 pengamatan berada di dalam batas kendali atau dengan kata lain dinyatakan in control. Maka peta kendali fuzzy demerit memiliki kasus out of control yang lebih tinggi daripada peta kendali demerit biasa.

Keputusan yang diperoleh baik dengan peta kendali demerit maupun fuzzy demerit adalah sama, yaitu terdapat banyak pengamatan yang dinyatakan out of control. Hal ini dapat disebabkan karena peta kendali demerit dan fuzzy demerit yang digunakan pada penelitian ini mengasumsikan bahwa data berdistribusi poisson, dimana nilai rata-rata dan varians yang dihasilkan setiap jenis cacat pada masingmasing line seharusnya memiliki nilai yang sama (tidak jauh berbeda). Namun pada kasus proses produksi kantong semen jenis pasted di PT. IKSG tahun 2017 memiliki nilai rata-rata dan varians yang jauh berbeda, sehingga menyebabkan terjadinya overdispersion. Langkah utama yang harus dilakukan untuk mengurangi banyak kasus out of control adalah perlu dilakukan upaya agar variasi jumlah cacat kantong semen yang terjadi menjadi minimum salah satunya dengan cara menyeragamkan kemampuan operator.

\section{Perbandingan Pengendalian Kualitas Kantong Semen} dengan Peta Kendali Demerit dan Fuzzy Demerit

Titik pengamatan yang dinyatakan out of control dengan peta kendali fuzzy demerit lebih banyak daripada dengan peta kendali demerit. Hal ini menunjukkan bahwa peta kendali fuzzy demerit lebih sensitif mendeteksi proses yang out of control dibanding peta kendali demerit. Selain jumlah titik out of control, kedua peta kendali juga menghasilkan keputusan yang berbeda, dimana ada beberapa titik yang sama-sama terdeteksi out of control di kedua peta kendali, ada pula beberapa titik yang terdeteksi out of control hanya di salah satu peta kendali.

Perbandingan titik out of control menunjukkan bahwa peta kendali fuzzy demerit lebih sensitif mendeteksi proses yang out of control dibanding peta kendali demerit. Namun, ada beberapa titik pengamatan yang dinyatakan out of control hanya pada peta kendali demerit dan dinyatakan in control peta kendali fuzzy demerit, sehingga kurang sesuai dengan kesensitivan peta kendali fuzzy. Hal tersebut dapat disebabkan oleh perbedaan perhitungan antara kedua peta kendali. Nilai statistik peta kendali demerit $\left(u_{j}\right)$ berdasarkan Persamaan (2) memberikan hasil jumlah cacat terboboti yang dibagi dengan banyak sampel setiap subgrup, namun tidak pada perhitungan nilai statistik peta kendali fuzzy demerit $\left(\tilde{D}_{j}\right)$ dengan Persamaan (9). Apabila terdapat subgrup dengan banyak sampel yang jauh dari standar satu palet perusahaan, yaitu sebanyak 3000 kantong semen, maka akan berakibat pada tingginya nilai statistik $u_{j}$ yang diperoleh di peta kendali demerit biasa. Sehingga nilai statistik $u_{j}$ yang tinggi tersebut mengakibatkan beberapa titik pengamatan terdeteksi out of control hanya di peta kendali demerit namun tidak di peta kendali fuzzy demerit.

\section{KESIMPULAN DAN SARAN}

\section{A. Kesimpulan}

Berdasarkan hasil analisis yang dilakukan, maka diperoleh kesimpulan bahwa proses produksi kantong semen jenis pasted selama periode Januari - Desember 2017 belum terkendali secara statistik baik menggunakan peta kendali demerit dan fuzzy demerit. Adanya pengamatan out of control dominan disebabkan oleh faktor manusia atau operator dalam proses pembuatan adonan lem, penyetelan mesin maupun bahan baku di awal produksi, kebersihan mesin, dan pemakaian mesin saat dilakukan perbaikan. Perbandingan pengendalian kualitas dengan peta kendali demerit dan fuzzy demerit dapat dilihat dari berapa banyak titik pengamatan yang dinyatakan out of control. Hasil analisis menunjukkan bahwa peta kendali fuzzy demerit lebih sensitif jika dibandingkan dengan peta kendali demerit karena peta kendali fuzzy demerit menangkap lebih banyak titik out of control daripada peta kendali demerit.

\section{B. Saran}

Saran yang dapat diberikan adalah perusahaan diharapkan mampu mengurangi nilai keragaman jumlah setiap jenis cacat yang saat ini masih tinggi, sehingga proses produksi akan lebih terkendali secara statistik. Upaya yang dapat dilakukan salah satunya adalah dengan menyeragamkan kemampuan operator seperti mengadakan pelatihan-pelatihan untuk karyawan, memberikan standard operating procedure (SOP) yang jelas untuk setiap penyetelan awal mesin, bahan baku, dan pembuatan adonan lem, serta melakukan penjadwalan kebersihan mesin secara rutin agar pembersihan mesin-mesin dapat dikerjakan lebih teratur oleh karyawan.

\section{DAFTAR PUSTAKA}

[1] Jones, L. A., Woodall, W. H., \& Conerly, M. D. (1999). Exact properties of demerit control charts. Journal of Quality Technology, 31(2), 207-216

[2] Chen, L. H. (2005). A demerit control chart with linguistic weights Journal of Intelligent Manufacturing, 16, 349-359.

[3] Cahyani, F. I. (2015). Analisis Pengendalian Kualitas Proses Pengantongan Semen di PT. Semen Indonesia (Persero) Tbk dengan Pendekatan Six Sigma. Surabaya: Institut Teknologi Sepuluh Nopember.

[4] Tasman, B., \& Yulius, H. (2016). Analisis Pengendalian Kualitas Kantong Semen Tipe Pasted Bag Menggunakan Metode Seven Tools (7QC) pada PT. Semen Padang. Jurnal Teknologi, 6(1), 51-63.

[5] Shu, M. H., Chiu, C. C., Nguyen, T. L., \& Hsu, B. M. (2014). A demerit-fuzzy rating system, monitoring scheme and classification for manufacturing processes. Expert Systems with Applications, 41, 7878-7888.

[6] Ramadhani, G. S., Yuciana, \& Suparti. (2014). Analisis Pengendalian Kualitas Menggunakan Diagram Kendali Demerit (Studi Kasus Produksi Air Minum dalam Kemasan $240 \mathrm{ml}$ di PT. TIW). Jurnal Gaussian, 3(3), 401-410.

[7] Montgomery, D. C. (2009). Introduction to Statistical Quality Control Sixth Edition. New York: John Wiley \& Sons, Inc. 